Gerontologia 1959;3:I-IV

\title{
Contents, Vol. 3, 1959
}

\section{Gerontologia}

Zeitschriftfürexperimentell-biologischeund-medizinischeAlternsforschung-Journal of Experimental Biological and Experimental Medical Research on Ageing - Journal de Recherches expérimentales, biologiques et médicales, sur le vieillissement

Editor :

F. Verzár, Basel

Coeditores :

R.E.Tunbridge

F. Bouriière C. M. McCay

Leeds

Paris

Ithaca, N.Y.

\section{COLLABORATORES:}

A. v. Albertini, Zurich

T. Gillman, Durban

W. Andrew,

E. Greppi, Firenze

Indianapolis, Ind.

J. Groen, Jerusalem

J. Baló, Budapest

L. Haranghy, Budapest

J. Banga, Budapest

E. Jalavisto, Helsinki

L. Binet, Paris

W.J. E.Jessup, Dublin

J. E. Birren, Bethesda, Md. 
V. R. Khanolkar, Bombay

G. H. Bourne,

P. S. Krishnan, Lucknow

Emory University, Ga.

P.J. Lindop, London

L. Brull†, Liège

K. Miescher, Basel

A. Comfort, London

O. Mühlbock, Amsterdam

J. Danielli, London

R. Nicolaysen, Oslo

W. Doberauer, Wien

F. Roulet, Basel

G. Di Macco, Roma

J. H. Sheldon, Wolverhampton

A. V. Everitt, Sydney

A. L. Vischer, Basel

K. J. Franklin, London

R. Wagner, München

T. Geill, København

A. Welford, Cambridge

1959

Vol. 3

BASEL (Schweiz) S. KARGER NEW YORK

Gömöri, Z.

Grafnetter, D. Grandjean, E. Griew, S. Hornsey, S. Histologische Yeränderungen in der Großhirnrinde von Ratten mit Yerlust des Erinnerungsvermögen $\beta$ im Alter 288

vide Zemplényi, $\mathrm{T}$.

vide Bättig, K.

A Further Note on Uncertainty in Relation to Age 335

Fertility and Lifespan of Mice Protected by Hypo

thermia against Total-Body Irradiation $\quad 128$

Hrachovec, J. P. and Rockstein, M. 
Age Changes in Lipid Metabolism and their Medical

Implications 305

Hruza, Z. vide Chvapil, M.

Kramer, H. vide Riedel, C.

Lieberman, M. H. vide Rockstein, $\mathrm{M}$.

Lindop, P. J. and Rotblat, J.

Shortening of Lifespan of Mice as a Function of Age

at Irradiation 122

Loutit, J. F. vide Barnes, D. W. H.

Meyer, A. und Verzár, F. Altersveränderung der Hydroxyprolin-Abgabe bei

der thermischen Kontraktion von KoUagenfasem . 184

Mole, R. H.

MÜHLBOCK, O. MUGGLETON, A.

Noble, N. L. Parrott, D. M. V.

Riedel, C. und Kramer, H.

Life Shortening by Multiple Doses of Irradiation . . 159 Factors Influencing the Life-Span of

Inbred Mice . . 177

vide Danielli, J. F.

vide Elden, H. R.

Ovarian Grafting as a Method for Research into

Ageing91

Über das Gerocomicon von Bernardino Stainer.

vide Lindop, P. J. vide Hrachovec, J. P.

Rotblat, J. Rockstein, M.

114

Rockstein, M. and Lieberman, H. M.

A Life Table for the Common House Fly, Musca

domestica 23

Said, F. S. and Weale, R. A.

Salvini, L. and Verdi, G.

Spink, J. M. Streicher, E.

The Variation with Age of the Spectral Transmissivi-

ty of the Living Human Crystalline Lens 213

Statistical Study on Correlation between Blood Level of Cholesterol, Beta/Alpha Lipoprotein

Ratio and Uric Acid of Normal and Arteriosclerotic Subjects . 327

vide Wright, E. A.

Age and Calcium Deposition in Rat Brain 97

Index

ORIGINAL PAPERS - ORIGINALARBEITEN - TRAVAUX ORIGINAUX

Alexander, P. vide Connell, D. I.

Alexander, P.; Connell, D. I.; Brohult, A. and Brohult, S.

Reduction of Radiation Induced Shortening of Life

Span by a Diet Augmented with Alkoxy Glycerol

Esters and Essential Fatty Acids 147

Bättig, K. und Grandjean, E. 
Beziehung zwischen Alter und Erlernen einer be-dingten Fluchtreaktion bei der weißen Ratte. . . .266

Barnes, D. W. H.; Loutit, J. F. and Westgarth, D. R.

Longevity of Radiation-Chimmaeras 137

Boucek, R. J. vide Elden, H. R.

Bourlière, $\mathrm{F}$. vide Clement, $\mathrm{F}$.

Brohult, A. vide Alexander, P.

Brohult, S. vide Alexander, P.

Chvapil, M. and Hruza, Z.

The Influence of Aging and Undernutrition on Che

mical Contractility and Relaxation of Collagen

Fibres in Rats 241

Clement, F. et Bourlière, F.

Remarques sur revolution avec 1'âge de quelques

tests de vocabulaire 5

Cole, L. J. Life Span Shortening in X- and Fast Neutron Irra

diated Mice 161

Connell, D. I. vide Alexander, P.

Connell, D. I. and Alexander, P.

The Incidence of Hepatomas in Irradiated and

Non-Irradiated CBA Male Mice as a Criterion of

Ageing 153

Danielli, J. F. and Muggleton, A.

Some Alternative States of Amoeba, with Special

Reference to Life-Span 76

Elden, H. R.; Noble, N. L. and Boucek, R. J.

The Swelling and Extractability of Human Sponge-

Biopsy Connective Tissue 204

Entwisle, D. G. A Preliminary Study of Age, Learning and Adapta

bility in the Rat 261

Everitt, A. V. The Effect of Prolonged Thyroxine Treatment on the

Ageing Male Rat 37,358

Everitt, A. V. The Effect of Indole-3-Acetic Acid on the Ageing

Male Rat 65

Garbus, J. vide Weinbach, E. C.

Talland, G. A. Facilitation of Accurate Perception by Anticipatory

Sets: the Progressive Effects of Aging 339

Verdi, G. vide Salvini, L.

Verzár, F. Influence of Ionizing Radiation on the Age Reaction

of Collagen Fibres 163

Verzár, F. Versuche über die Beeinflussung der Alterskreati-

nurie durch Alpha-Tokophcrolacetat und Selenium. 232

Verzár, F. Note on the Influence of Procain (Novocain), Para-

aminobenzoicacid or Diethylethanolamin on the

Ageing of Rats 351

Verzár, F. vide Meyer, A. 
Weale, R. A. vide Said, F. S.

Weinbach, E. C. and Garbus, J.

Coenzyme A Content and Fatty Acid Oxidation in Liver and Kidney Mitochondria from Aged Rats . 253

Westgarth, D. R. vide Barnes, D. W. H.

Wright, E. A. and Spink, J. M.

A Study of the Loss of Nerve Cells in the Central

Nervous System in Relation to Age 277

Zemplényi, T. and Grafnetter, D.

The Lipolytic Activity of the Aorta, its Relation to

Ageing and to Atherosclerosis 55

CRITICAL REVIEW - ÜBERSICHTSREFERAT - REVUE GÉNÊRALE

Editorial 104

Gordon, H. A. The Use of Germfree Vertebrates in the Study of

"Physiological Effects" of the Normal Microbial

Flora 104

Editorial 121

Book Reviews - Buchbesprechungen - Livres Nouveaux 119, 171, 359

News Items - Nachrichten - Nouvelles 119, 176, 240

Obituaries - Nachrufe - Necrologies

Dr. Dr. h. c. Heinz Karger 1

V. Korenchevsky 117

Register rerum ad Vol. $3 \quad 362$

Alle Rechte, insbesondere das der Übersetzung in fremde Sprachen, vorbehalten.

Ohne ausdrückliche Genehmigung des Verlages ist es auch nicht gestattet, diesen Band oder

Teile daraus

auf photomechanischem Wege (Photokopie, Mikrokopie) zu vervielfältigen.

(C)

Copyright 1959 by S. Karger AG, Basel

Printed in Switzerland by Buchdruckerei National-Zeitung AG, Basel

Cliches: Aberegg-Steiner \& Cie. AG, Bern, und Steiner \& Cie. AG, Basel 